V. Goleus, A. Salei

\title{
Effect of Transition Metals Oxide Additives on the Properties of Mixed-Alkali Glass for Electric Insulating Coatings on Aluminum
}

\author{
Ukrainian State University of Chemical Technology,Dnipro, 49000,Ukraine, udhtu@udhtu.edu.ua
}

\begin{abstract}
In order to reduce the cost of the thick-film technology of microcircuits and heating elements, as well as to expand its areas of use, it became necessary to expand the range of materials that, along with ceramics and steel, can also be used as substrates for these products. One of these advanced materials is aluminum. Enamels for aluminum should be subjected to roasting at relatively low temperatures, and therefore contain an increased amount of alkali metal oxides in their composition, which causes low values of chemical resistance and volume of electrical resistivity. Electrically insulated coatings on metals are subjected to repeated heating and cooling while their produce and use, which promotes the creation of temperature stresses in the coating and leads to their chipping. Therefore, in order to improve the water resistance and adhesion strength of electrical insulation coatings on aluminum, $\mathrm{CuO}, \mathrm{ZrO}_{2}$ and $\mathrm{Bi}_{2} \mathrm{O}_{3}$ additives were examined. There was found an increase in water resistance with a simultaneous increase in the adhesion strength of the enamel coating with an aluminum substrate with the addition of not more than 3 pts. wt. of copper oxide (II), up to 1 pts. wt. of zirconium oxide (IV), and up to 4 pts. wt. of bismuth oxide (III) w.r.t. 100 pts. wt. of glass.
\end{abstract}

Keywords: enamels on aluminum, water resistance, electrical insulating coatings, contact layer, flowability, adhesion strength.

Article acted received 13.07.2019; accepted for publication 15.09.2019.

\section{Introduction}

The basis of modern technical progress is the development of chemical compositions and technological parameters for obtaining new glass enamel coatings for various metal substrates [1]. Recently, electric film heater have been increasingly used in the instrument engineering and in the production of household electrical heating equipment.

Literature review. The need for electrical insulation coatings on aluminum in the manufacture of low-power film heaters is caused by the technical and economic feasibility of replacing ceramic substrates for the metal ones. In this regard, additional requirements of performance are imposed on enamel coatings, in addition to their anti-corrosion and decorative properties. These characteristics of enamel coatings include increased values of their heat resistance, chemical resistance, electrical insulation and other properties [2].

As is known, aluminum is characterized by a high value of the temperature coefficient of linear expansion (TCLE) $\left(230 \cdot 10^{-7} \mathrm{~K}^{-1}\right)$ and a low melting temperature $\left(\sim 650^{\circ} \mathrm{C}\right)$. Known compositions of glass frit to obtain coatings on aluminum due to the need to form them by roasting at a temperature of $550-580^{\circ} \mathrm{C}$ contain a significant amount of alkali metal oxides and therefore cannot be used as electrical insulating. To improve the electrical properties of enamels for aluminum, lead oxide is added into their composition by reducing the content of alkali oxides [1, 3-5]. However, this oxide tends to interact with the components of conductive pastes to form metallic lead, which contributes to a decrease in the electrical strength of the coating.

Strong adhesion of the enamel coating to the metal substrate is an important component of the durability of the use of enameled products [1, 3, 6-11]. It is known that when enameling aluminum, the adhesion strength of the coating to the substrate depends on the ability of the oxide film to dissolve in the enamel melt and the thickness of the transition layer [3].

\section{Object}

Therefore, the object of the work was to develop the oxide composition of electric glass for obtaining enamel coating on aluminum with increased water resistance and to investigate the effect of transition metal additives on the formation of a contact layer in the aluminum-enamel system. 
Table 1

Physical and chemical properties of glass for the production of coatings on aluminum

\begin{tabular}{|c|c|c|c|}
\hline $\begin{array}{c}\text { Water resistance (amount of } 0.01 \mathrm{~N} \mathrm{HCl} \text { which } \\
\text { was used for titration) }, \mathrm{cm}^{3} / \mathrm{g}, \text { (dimming class) }\end{array}$ & $\begin{array}{c}\text { TCLE } 10^{-7}, \mathrm{~K}^{-1} \\
\left(20-400^{0} \mathrm{C}\right)\end{array}$ & $\mathrm{MT},{ }^{0} \mathrm{C}$ & $\begin{array}{c}\text { Electrical resistivity at } \\
150^{0} \mathrm{C}, \Omega \cdot \mathrm{cm}\end{array}$ \\
\hline $3.55(5 / 98)$ & 164.5 & 448 & $10^{9.8}$ \\
\hline
\end{tabular}

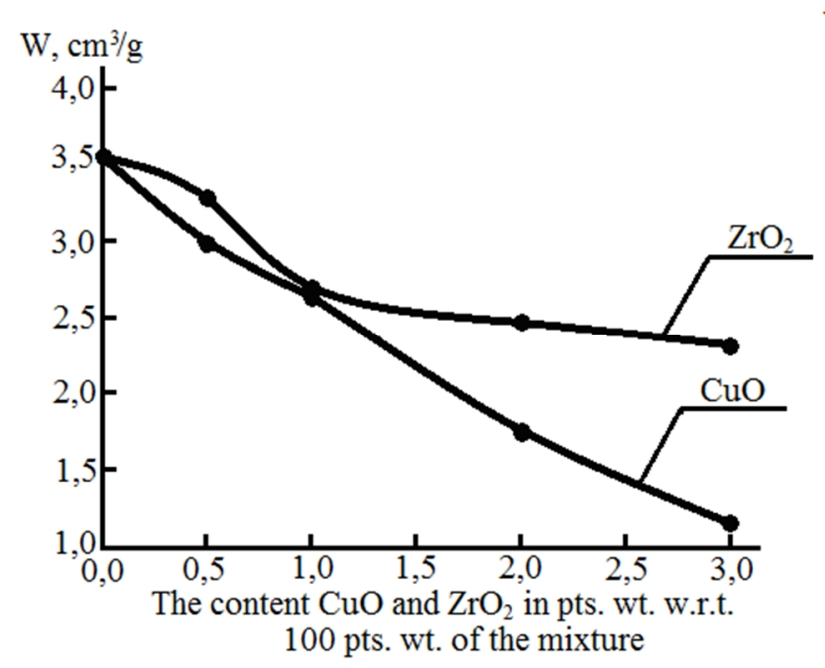

a)

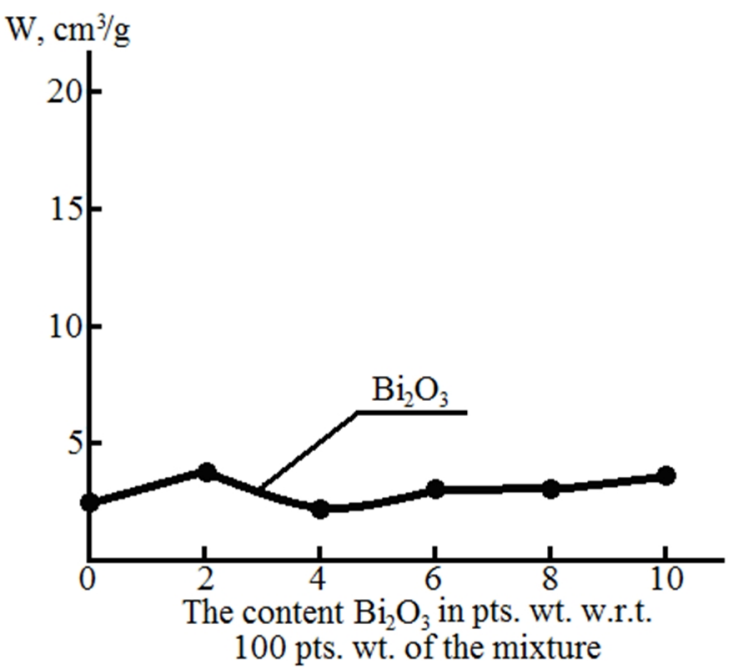

b)

Fig. 1. The dependence of the enamel water resistance for aluminum on $\mathrm{CuO}, \mathrm{ZrO}_{2}$ (a) and $\mathrm{Bi}_{2} \mathrm{O}_{3}$ (b) additives.

\section{Methods}

For the synthesis of glass under research were used quartz sand and soda of technical purity; lithium, potassium, strontium, barium carbonates, titanium dioxide and trisodium phosphate of pure grade; boric acid, oxides of zinc, copper (II) and zirconium (IV) of analytical grade, as well as bismuth (III) oxide of extrapure grade.

Glass melting was carried out in fireclay crucibles in an electric furnace with carborundum heaters with an exposure time of 30-40 minutes at a temperature of 1150$1180^{\circ} \mathrm{C}$. The readiness of the glass is determined by the visual test of the thread. Melts of glass under research were granulated by pouring into cold water. To determine the physicochemical properties of the glass, samples were made from glass bubble-free metal by casting into steel molds.

Experimental studies of the properties of the glass were performed using standard methods and measuring instruments that were generally recognized and widely used in glass chemistry and technology:

- dilatometer investigation of the thermal coefficient of linear expansion (TCLE) and melting temperature (MT) were determined on a DKV-5A quartz dilatometer in accordance with GOST 10978-83;

- electrical resistivity was determined using E6-13A teraohmmeter;

- chemical resistance of glass was determined by the grain method in accordance with GOST 10134.1-82;

- the structure of the contact layer of aluminum and enamel was examined on a REMMA-102-02 scanning electron microscope.

Insulating coatings on metal obtained under the slurry and roasting technology. The coating was applied on aluminum by pouring. Preparation of products from aluminum before coating consisted of treatment in an alkaline solution of a chromic acid salt according to the recipe, which is given in [3].

Slurry for coatings on aluminum was crushed to pass through sieve No. 0045 in porcelain drums with uralite grinding charge in isopropyl alcohol environment. The roasting of electrical insulation coatings was carried out in a muffle furnace at a temperature of $580{ }^{\circ} \mathrm{C}$ for $15-20$ minutes.

\section{Results}

Due to calculation and experimental studies it was established [12] that the basis for producing electrical insulating coatings on aluminum was mixed-alkali borosilicate glass of the following composition, mol. \%: $\mathrm{SiO}_{2}+\mathrm{TiO}_{2}-54, \mathrm{BaO}+\mathrm{SrO}+\mathrm{ZnO}-5 ; \mathrm{B}_{2} \mathrm{O}_{3}+\mathrm{P}_{2} \mathrm{O}_{5}-$ 5; $\mathrm{Li}_{2} \mathrm{O}+\mathrm{Na}_{2} \mathrm{O}+\mathrm{K}_{2} \mathrm{O}-36$. This glass is characterized by the following properties, which are represented in Table 1.

In order to increase chemical resistance and reduce surface tension, $\mathrm{CuO}$ and $\mathrm{ZrO}_{2}$ additives in the amount of 0.5-3.0 pts. wt. w.r.t. 100 pts. wt. of the mixture and $\mathrm{Bi}_{2} \mathrm{O}_{3}$ additives in the amount of 2-10 pts. wt. w.r.t. 100 pts. wt. of the mixture were added to the composition of glass. Figures 1-4 show the dependences of water resistance $(W)$, electrical resistivity $\left(\lg \rho_{150}\right)$, TCLE and 


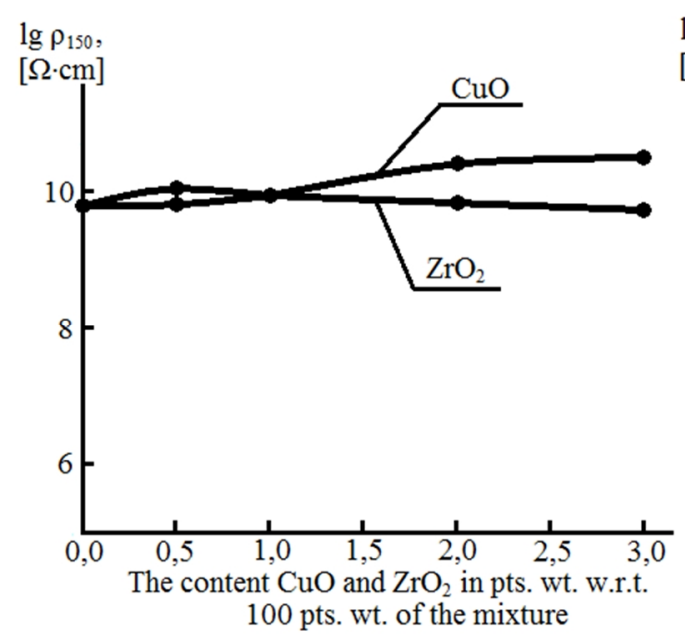

a)

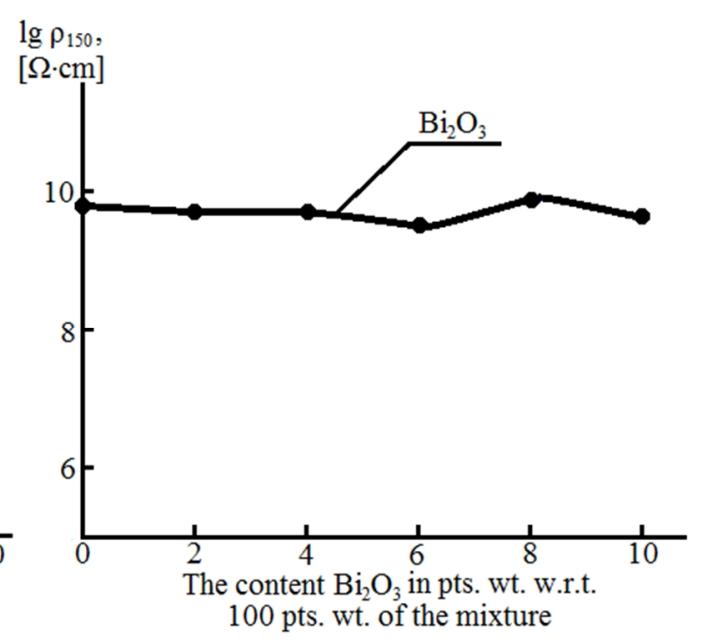

b)

Fig. 2. The dependence of the electrical resistivity at $150^{\circ} \mathrm{C}$ of enamel for aluminum on the $\mathrm{CuO}, \mathrm{ZrO}_{2}$ (a) and $\mathrm{Bi}_{2} \mathrm{O}_{3}$ (b) additives.

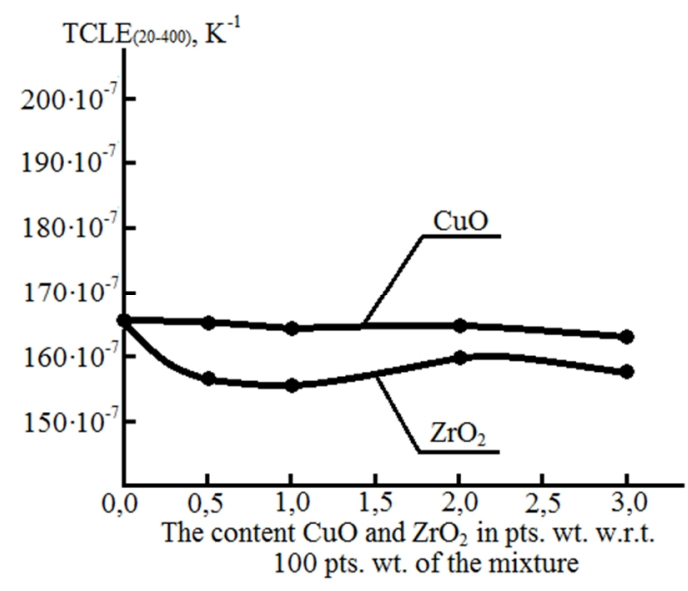

a)

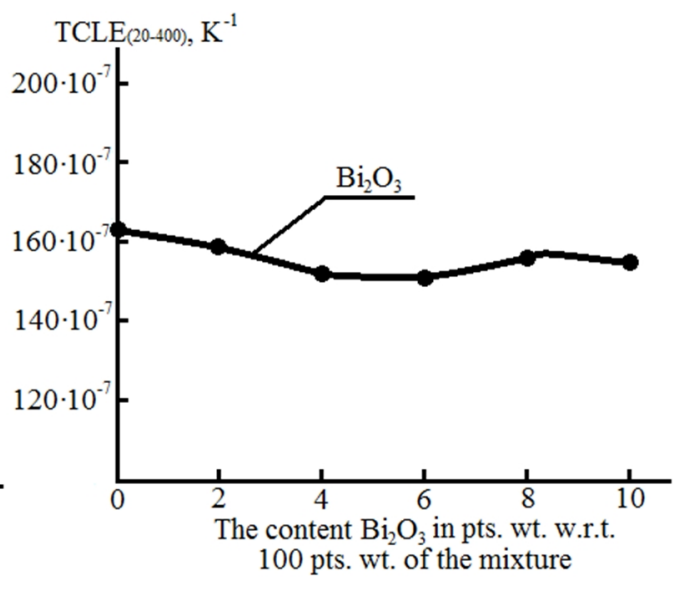

b)

Fig. 3. The dependence of the TCLE of enamel for aluminum on $\mathrm{CuO}, \mathrm{ZrO}_{2}$ (a) and $\mathrm{Bi}_{2} \mathrm{O}_{3}$ (b) additives.

MT of glass on the content of additives of these oxides in its composition.

It has been established (Fig. 1, a) that the addition of zirconium dioxide and copper oxide additives into the composition of this glass contributed to an increase in water resistance, which was characterized by a decrease in the amount of $0.01 \mathrm{~N} \mathrm{HCl}$ solution, which was used for aqueous extract titration, from 3.55 to $1.10 \mathrm{ml}(4 / 98$ dimming class). It should be noted that $\mathrm{CuO}$ additives contributed to an increase in electrical resistivity from $10^{9.8}$ to $10^{10.5} \Omega \cdot \mathrm{cm}$ and did not affect the TCLE of the enamel $\left(165 \cdot 10^{-7} \mathrm{~K}^{-1}\right)$, while the addition of $\mathrm{ZrO}_{2}$, on the contrary, contributed to a slight decrease of TCLE to $155 \cdot 10^{-7} \mathrm{~K}^{-1}$, and the value of electrical resistivity did not change (Fig. 2-3, a).

The addition of bismuth oxide to the composition of this glass has an ambiguous effect on chemical resistance, possibly due to a change in the bismuth valence (Fig. 1, b). Its presence practically does not affect the value of TCLE, MT and electrical resistivity, but significantly improves the spreading of enamel on aluminum (Fig. 2-4, b).

\section{Discussion}

It has been established that the addition of zirconium dioxide and copper oxide additives to the composition of the glass under research contributed to an increase in water resistance, which even at a content of up to 3 pts. wt. w.r.t. 100 pts. wt. of the mixture increased the water resistance of the glass frit almost 1.5-3.0 times, respectively. At the same time, the increase of the $\mathrm{ZrO}_{2}$ additive in the enamel leads to a slight decrease in TCLE to $155 \cdot 10^{-7} \mathrm{~K}^{-1}$ and increase in the temperature of the melting temperature to $455^{\circ} \mathrm{C}$, therefore the content of this component should not exceed 1 pts. wt. w.r.t. 100 pts. wt. of the mixture. The recommended content of $\mathrm{Bi}_{2} \mathrm{O}_{3}$ should not exceed 4 pts. wt. w.r.t. 100 pts. wt. of the mixture due to the occurrence of recovery processes in the formation of the coating.

According to the results (Fig. 5) of these 


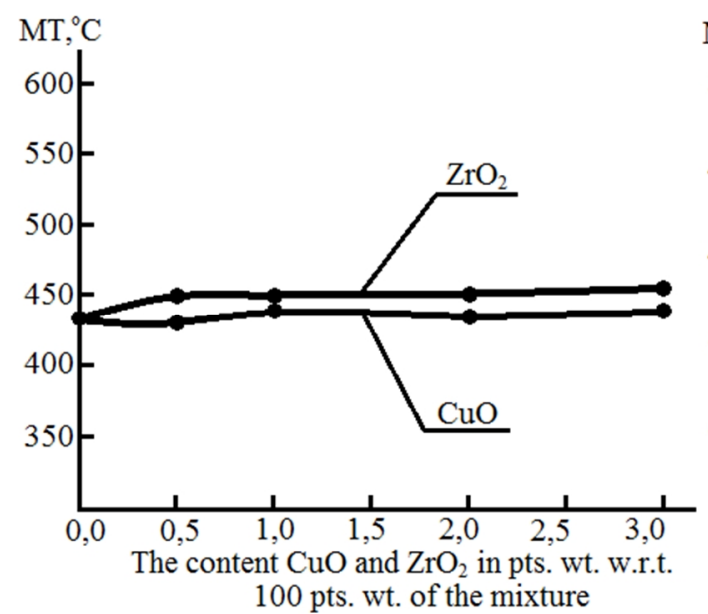

a)

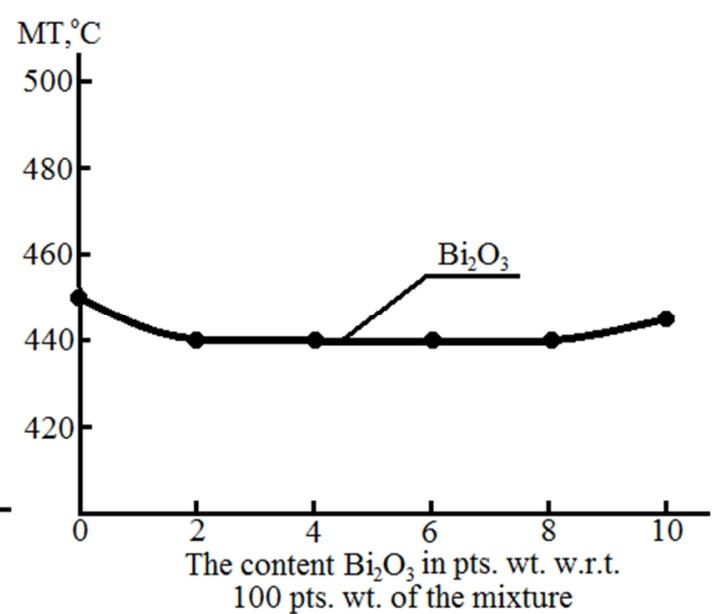

b)

Fig, 4. The dependence of MT of enamel for aluminum on the of $\mathrm{CuO}, \mathrm{ZrO}_{2}$ (a) and $\mathrm{Bi}_{2} \mathrm{O}_{3}$ (b) additives.

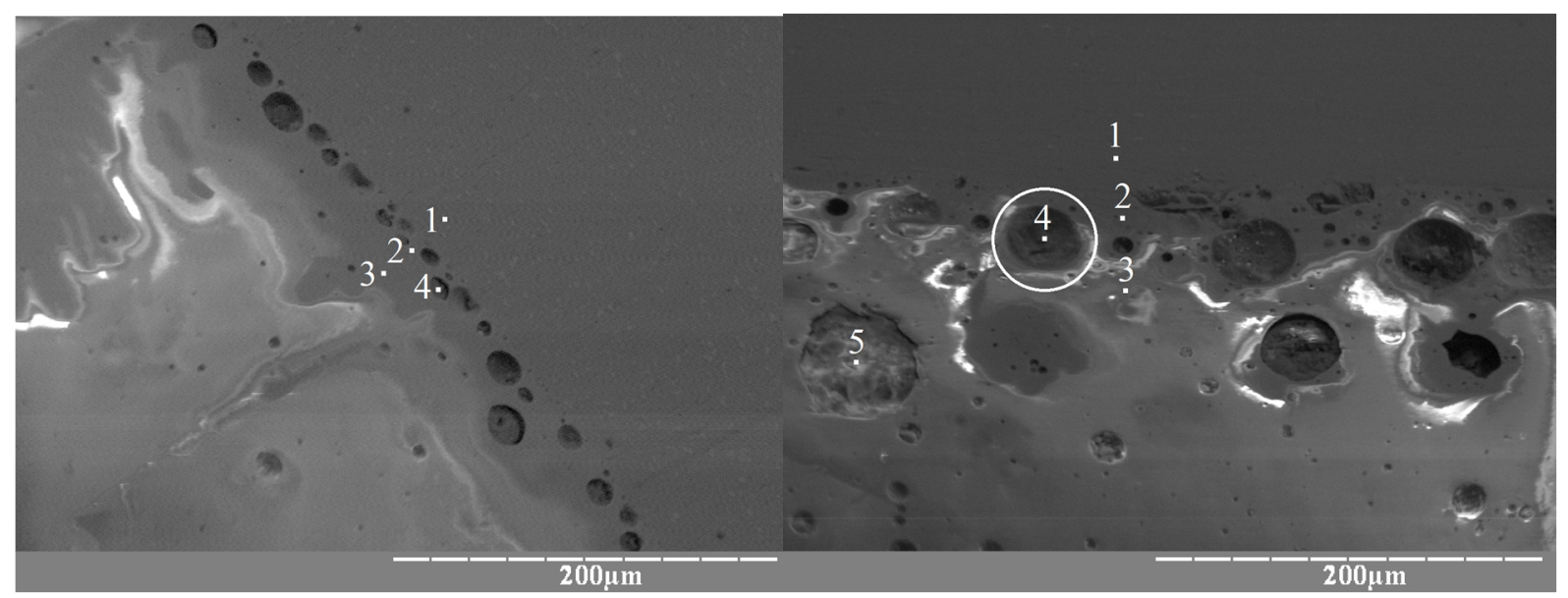

a)

b)

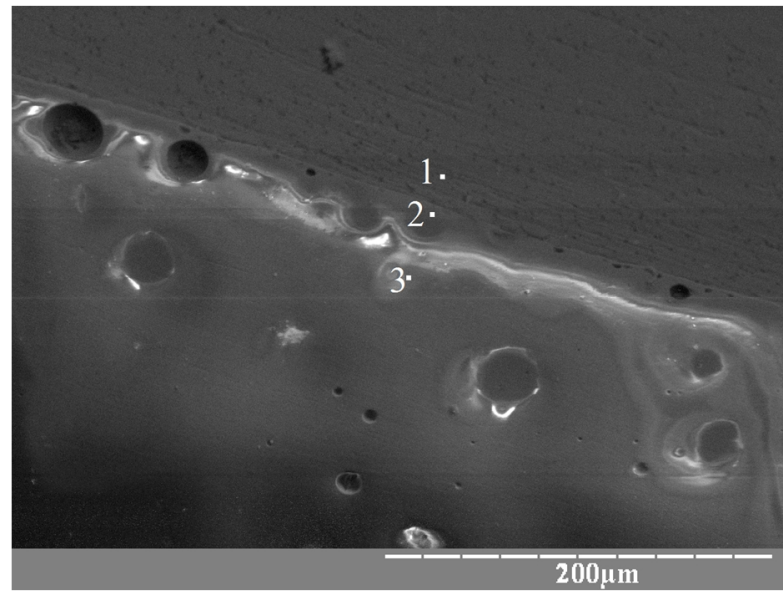

c)

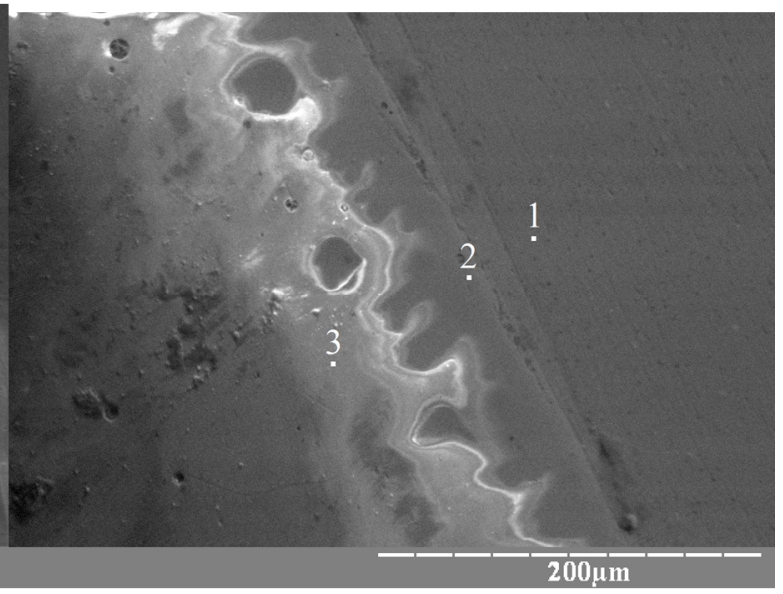

d)

Fig. 5. SEM-micrograph of cross-sections of the sample with a coating based on enamel for aluminum (a), as well as enamels with additions of 4 pts. wt. of $\mathrm{Bi}_{2} \mathrm{O}_{3}$ (b), 1 pts. wt. of $\mathrm{ZrO}_{2}$ (c) and 3 pts. wt. of $\mathrm{CuO}$ (d): 1 - aluminum;

$$
2 \text { - contact zone; } 3 \text { - enamel; 4,5 - additional points. }
$$

examinations of the structure and chemical composition of the aluminum and enamel contact layer, the effect of $\mathrm{CuO}, \mathrm{ZrO}_{2}$ and $\mathrm{Bi}_{2} \mathrm{O}_{3}$ additives with the abovementioned concentrations in the glass composition on the flowability and coating formation parameters was found [13].
Micrographs of the cross-section of the sample with enamel coating do not show a clear boundary of the contact layer, which indicates a deep penetration of enamel into the intermediate zone.

From the presented on the Fig. 6 examination results there was revealed that the copper oxide additive 


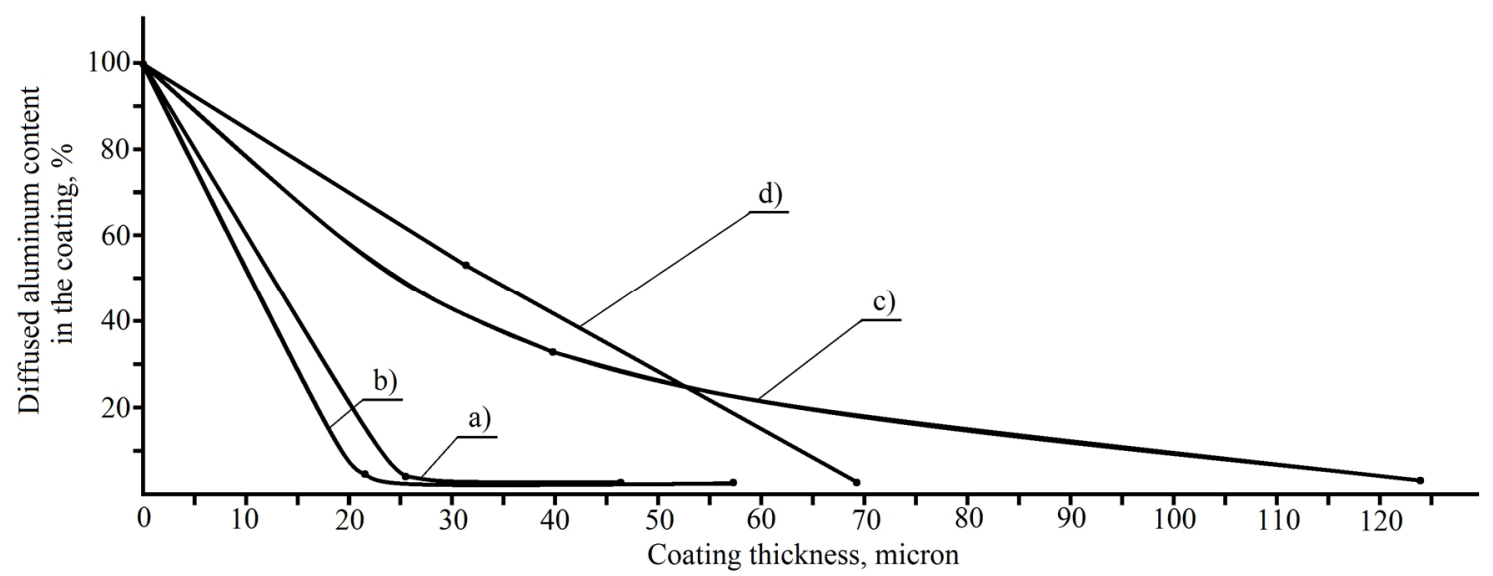

Fig. 6. Aluminum distribution in the aluminum - contact zone - enamel system: a) enamel for aluminum; b) the same with 1 pts. wt. of $\mathrm{ZrO}_{2}$ w.r.t. 100 pts. wt. charge; c) the same with 3 pts. wt. of $\mathrm{CuO}$ w.r.t. 100 pts. wt. of the mixture; d) the same with 4 pts. wt. of $\mathrm{Bi}_{2} \mathrm{O}_{3}$ w.r.t. 100 pts. wt. of the mixture.

contributed to a more uniform distribution of aluminum oxide throughout the enamel thickness, which contributed to the expansion of the contact zone, and accordingly, an increase in the adhesion strength of the enamel coating to the aluminum substrate.

Bismuth oxide also acts as a surface-active component, which is in good agreement with known ideas about the structure of the glass [14]. While sorbing on aluminum enamel on the interface it improves the flowability of enamel over the metal surface, which is confirmed by chemical analysis data (Fig. 6) and visual assessment of the coverglass. In Fig. 5 (b) the area with the increased content of bismuth oxide is marked with a white circle.

\section{Conclusion}

It has been established that to the greatest extent the addition of copper oxide and zirconium dioxide additives to the composition of glass contributed to the increase in its water resistance and electrical resistivity. At the same time, spreading and strong adhesion of enamel coating to aluminum is achieved by addition of bismuth and copper into the composition of the oxide. As a result of these studies it was found that not more than 3 pts. wt. of copper oxide (II), up to 1 pts. wt. of dioxide (IV) zirconium, and up to 4 pts. wt. of bismuth oxide (III) w.r.t. 100 pts. wt. of the glass, respectively, should be in the enamel for electrical purposes to ensure the required characteristics of water resistance, TCLE, MT, electrical resistivity and adhesion strength.

Goleus V. - Professor, Doctor of Technical Sciences, Vice-rector for scientific and pedagogical work, Head of the Department of Chemical Technology of Ceramics and Glass;

Salei A. - PhD, Assistant Professor, Department of Chemical Technology of Binder.

[1] L.L. Bragina, A.P. Zubehin, Ja.I. Belyj, V.A. Guzij, Ju.K. Kazanov, Tehnologija jemali i zashhitnyh pokrytij (NTU "HPI", JuRGTU (NPI), Har'kov, Novocherkassk, 2003).

[2] A.A. Appen, Temperaturoustojchivye neorganicheskie pokrytija (Himija, Leningrad, 1976).

[3] V.V. Vargin, Jemalirovanie metallicheskih izdelij (Mashgiz, Moskva, 1972).

[4] Pat. 2036868 C1 Rossijskaja Federacija, MPK ${ }^{6}$ C 03 C 8/24, C 03 C 3/072. Steklo preimushhestvenno dlja izoljacii aljuminievoj prodnikovoj razvodki [Text] / A.I. Ermolaeva, N.I. Koshelev, A.N. Ivljushkin; zajavitel' i patentoobladatel' Moskovskij institut jelektronnoj tehniki. - № 5058478/33; zajavl. 11.08.92; opubl. 09.06.95, Bjul. №16.

[5] A.s. 1119990 A SSSR, МКИ C 03 C 7/08. Jemal' [Text] / I.A. Shulc, G.P. Sedmale, U.Ja. Klimanskij (SSSR). - № 3571784/29-33; zajavl. 04.04.83; opubl. 23.10.84, Bjul. № 39.

[6] V.V. Vargin, E.P. Antonov, L.P. Gutorova, Tehnologija jemali i jemalirovanija metallou (Gosstrojizdat, Moskva, 1958).

[7] A. Petcol'd, Jemal' i jemalirovanie (Metallurgija, Moskva, 1990).

[8] A. Petcol'd, Jemal' (Metallurgizdat, Moskva, 1958).

[9] B. Rous, Steklo v jelektronike (Sovetskoe radio, Moskva, 1969).

[10] O.V. Mazurin, A.S. Totesh, M.V. Strel'cina, T.P. Shvajko-Shvajkovskaja, Teplovoe rasshirenie stekla (Nauka, Leningrad, 1969).

[11] S.I. Djakivs'kij, T.B. Zheplins'kij, J.M. Jashhishin, Termichne obroblennja i napruzhennja u skli (Vidavnictvo NU "L'vivs'ka politehnika", L'viv, 2003). 
[12] V.I. Goleus, T.F. Shul'ga, Visnik $\quad$ NTU "HPI" №22, $14 \quad$ (2009) (doi: http://repository.kpi.kharkov.ua/handle/KhPI-Press/30709).

[13] An.A. Salej, T.F. Shul'ga, V.I. Goleus, Mezhdunarodnaja nauchno-tehnicheskaja konferencija "Fizikohimicheskie problemy v tehnologii tugoplavkih nemetallicheskih i silikatnyh materialov" (DVNZ UDHTU, Dnipropetrovs'k, 2013). S. 101.

[14] A.A. Appen, Himija stekla (Himija, Leningrad, 1974).

\author{
В.І. Голеус, А.А. Салєй
}

\title{
Вплив добавок оксидів перехідних металів на властивості полілужного скла для електроізоляційних покриттів на алюмінії
}

\author{
Державний вищий навчальний заклад "Украӥнський державний хіміко-технологічний університет" (ДВНЗ УДХТУ), \\ Дніпро, 49000, Україна, иdhtи@иdhtu.еdи.иа
}

\begin{abstract}
3 метою здешевлення товстоплівкової технології мікросхем і нагрівальних елементів, а також 3 метою розширення областей іiі застосування виникла потреба в розширенні кола матеріалів, які поряд 3 керамікою і сталлю можуть також використовуватися в якості підкладок для зазначених виробів. Одним 3 таких перспективних матеріалів $\epsilon$ алюміній. Однак технологія отримання електроізоляційних склоемалевих покриттів на алюмінії ще недостатньо розроблена. Пов'язано це $з$ тим, що емалі для алюмінію обпалюють при відносно низьких температурах, і тому містять в своєму складі підвищену кількість оксидів лужних металів, що обумовлює низькі значення хімічної стійкості та питомого об'ємного електричного опору. Електроізоляційні покриття на металах в процесі їх виготовлення та експлуатації піддаються багаторазовому нагріванню та охолодженню, що сприяє до створення термічних напружень в покритті і призводить до їх відколювання. Тому з метою підвищення водостійкості та міцності зчеплення електроізоляційних покриттів на алюмінії були дослідженні добавки $\mathrm{CuO} \mathrm{i} \mathrm{ZrO}_{2}$ в кількості 0,5 - 3,0 мас.ч понад 100 мас.ч шихти і добавки $\mathrm{Bi}_{2} \mathrm{O}_{3}$ в кількості 2 - 10 мас.ч понад 100 мас. ч шихти. Встановлено підвищення водостійкості при одночасному збільшенню міцності зчеплення емалевого покриття з алюмінієвою підкладкою при введенні не більше 3 мас.ч. оксиду (II) міді, до1 мас.ч. оксиду (IV) цирконію, а також до 4 мас.ч. оксиду (III) вісмуту понад 100 мас. частин скла.

Ключові слова: емалі на алюмінії, водостійкість, електроізоляційні покриття, контактний шар, розтічність, міцність зчеплення.
\end{abstract}

